\title{
Political Theory and the European Constitution
}

Lynn Dobson and Andreas Follesdal (eds.)

Routledge, London and New York, 2004, 224pp.

ISBN: 0415340675.

Contemporary Political Theory (2007) 6, 120-122. doi:10.1057/palgrave.cpt.9300289

The collection of essays under review was written before the current impasse in the still on-going process of writing and ratifying the European constitutional treaty. This is noticeable in some of the contributions and in the more general frame of the volume, but in spite of this, the essays in the collection still maintain a topical interest. As the editors note, the book strides a midway line between optimistic and pessimistic visions of the scope and achievements of a European constitution, by addressing 'the important interplay between normative standards and institutional design' (p. 184) that lies at the heart of writing and judging a document of constitutional nature. Their general assessment of the process of writing the constitution and of the draft text that emerged from the Convention is that both the text and the process contribute to the normative legitimation of the European polity, but that it would be wrong to see the process as approaching an ideal-speech situation, or the constitutional text as a way of foreclosing political discussion and political conflict in the European polity.

The essays comprising the volume cover three main aspects of the way in which the European constitution matters to the legitimacy of the European Union. A first group engages with the way in which writing the constitution relates to the 'divided' nature of the European polity; a second discusses the character of the constitution-making process itself; and the final, and more numerous group, discusses some of the substantive values underlying the constitutional document and the kind of treatment they receive in the constitutional text itself. The essays by Schmitter, McKay, and Kraus are concerned with the institutional and cultural aspects involved in combining unity with diversity in the European Union. From quite different perspectives, Schmitter and McKay discuss the 'federal' question. Although both remark that concerns on whether the federal label fits the EU are in the first instance a matter of semantics, their own attempts are of a more substantive nature. McKay adopts a rational choice framework to test whether the constitutional settlement emerging from the draft constitution is capable of creating a sustainable federal structure for the EU. The main thrust of his argument is that, in rational choice terms, a sustainable federation needs an incentive structure facilitating intra-elite bargaining and mediation. Although this seems to be partly in place in the EU, McKay believes that there is a fundamental asymmetry in decision-making structures between fiscal and monetary policies, 
something that may affect the legitimacy and eventually the effectiveness of the EU federal system. Schmitter's contribution is more general, and more questioning of the applicability of a federal structure to the EU. His argument is that those conditions that make the EU different from a traditional state make it also difficult for it to be organized as a federation. The structure of diffuse 'governance' that characterizes the EU seems irreducible to those key features, such as clearly divided competences, formal symmetry, decentralized democracy, etc. that mark federal states. Besides, the conditions for a sudden and dramatic transformation of the present, mainly nation-based, political structures are absent in Europe. So that in Schmitter's view the timing for an acceleration of the constitutionalization process in the EU and the imposition of a quasi-federal structure is simply wrong. With time, instead, and by 'deliberately politicizing', the European issues and 'gradually building expectations' (p. 21) for European-wide rules, political representation, and citizenship, it may be possible to create the conditions for both the federalization, the democratization and the constitutionalization of the European polity. Kraus tackles the issue of unity and diversity from a more cultural perspective. He notices how the normative assumptions made by traditional liberal and democratic theory, on the need for a certain level of cultural and linguistic homogeneity for democracy to work, do not fit the multinational character of the EU. But he also remarks on the rather unthinking way in which appeals to the preservation of diversity within the European integration process have ultimately resulted in a 'more or less continuous reproduction of national structures' (p. 51). Kraus's own view is that European integration departs from models of national rule and that its legitimacy depends on the development of a form of democratic interculturalism based on the constitutional embodiment of the principle of recognition.

Although the essay by Bellamy and Schönlau, and partly that by Olsen are the only two ostensibly devoted to the question of what kind of legitimacy the constitution-making process itself contributes to the formation of a European polity, this is a theme indirectly touched upon by other contributions such as, as we have seen, Schmitter's, or others more directly concerned with the substantive values enshrined in the constitutional text. The central argument in Bellamy and Schönlau is that the legitimation that constitution making confers to the polity does not depend on an idealized view of its proceedings or on how agreement is reached. This view of constitutional deliberation is overblown both normatively and empirically. From an empirical perspective, the essay shows the kind of compromises on which agreements were reached during the constitutional convention, and how these differed both in function of what was that the parties actually did in order to arrive at a compromise, and in relation to the quality of outcome that they achieved by agreeing to compromise on certain positions. From a normative perspective, the essay agues that 
compromise is not a suboptimal solution, for the kind of consensus and normative agreement that is often thought necessary for constitutional politics to work is both unrealistic and contrary to a political conception of pluralism. For his part, Olsen explores the question of whether a public philosophy emerges from the Convention proceedings and the draft constitution, and whether such public philosophy offers a reasonable vision of Europe. His answer, however, is that though the constitution-making process has contributed to the emergence of a democratic dialogue on a European public philosophy, this is far from settled and the discussion over the constitution must carry on.

As for the contributions on the substantive values of the constitutional document, it is difficult to do justice to them in the brief compass of this review. The topics covered go from the idea of liberty (Dobson) to representation (Smisman) and transparency (Naurin); from the role of rights and judicial power (Attucci and Gargarella, respectively) to new practices of decision making such as the Open Method of Co-ordination (Tsakatika). As the editors remark in their conclusion, besides offering some illuminating insights on the legitimacy of the European integration process, the application of the normative approach to the European constitutional debate provides elements of reflection on political theory itself, and how many of the categories and distinctions that characterize more abstract debates are often presented in too stark terms, while the application of political theorizing to concrete situations may require a more nuanced adaptation so as to capture the multi-dimensional aspects of political reality.

Dario Castiglione University of Exeter, UK.

\section{Pluralism}

William E. Connolly

Duke University Press, Durham NC and London, 2005, 208pp. ISBN: 0822335670.

Contemporary Political Theory (2007) 6, 122-125. doi:10.1057/palgrave.cpt.9300292

William Connolly has written about pluralism for quarter of a century. Over the past 10 years, he has developed his own distinctive 'post-Nietzschean' conception of 'multidimensional pluralism'. Pluralism resembles Connolly's previous publications both in terms of its form and content. This is not a criticism, there is difference in Connolly's repetitions, and this is an important 